University of Michigan Law School

University of Michigan Law School Scholarship Repository

Articles

Faculty Scholarship

2021

\title{
Funding Global Governance
}

\section{Kristina B. Daugirdas}

University of Michigan Law School, kdaugir@umich.edu

Available at: https://repository.law.umich.edu/articles/2274

Follow this and additional works at: https://repository.law.umich.edu/articles

Part of the Environmental Law Commons, International Law Commons, and the Public Law and Legal Theory Commons

\section{Recommended Citation}

Daugirdas, Kristina. "Funding Global Governance." NYU Environmental Law Journal 29, no. 3 (2021): 639-658.

This Article is brought to you for free and open access by the Faculty Scholarship at University of Michigan Law School Scholarship Repository. It has been accepted for inclusion in Articles by an authorized administrator of University of Michigan Law School Scholarship Repository. For more information, please contact mlaw.repository@umich.edu. 


\title{
FUNDING GLOBAL GOVERNANCE
}

\author{
KRISTINA DAUGIRDAS
}

\begin{abstract}
Funding is an oft-overlooked but critically important determinant of what public institutions are able to accomplish. This article focuses on the growing role of earmarked voluntary contributions from member states in funding formal international organizations such as the United Nations and the World Health Organization. Heavy reliance on such funds can erode the multilateral governance of international organizations and poses particular risks for two kinds of undertakings: normative work, such as setting standards and identifying best practices; and evaluating the conduct of member states and holding those states accountable, including through public criticism, when they fall short. International organizations have devised strategies for mitigating these risks, but those strategies are generally not codified in formal policies and are not visible to the public. This Article argues that more formal regulations are needed and outlines some possibilities for the form they might take.
\end{abstract}

INTRODUCTION 639

I. WHY WORRY?

II. REGULATION OF VOLUNTARY CONTRIBUTIONS FROM MEMBER STATES 647

A. Formal and Informal Policies and Practices at WHO .648

B. Problems with Reliance on Informal Practices

III. NEXT STEPS 656

CONCLUSION 658

\section{INTRODUCTION}

To my great fortune, my time as a student at New York University School of Law coincided with Dick Stewart and Benedict Kingsbury's launching of the Global Administrative Law project. During my second year of law school, I joined their colloquium on Globalization and Its Discontents. Many of the papers presented that semester constituted the core of early work on global administrative law. ${ }^{1}$ The following year, I became a Furman Scholar and

* Professor of Law and Associate Dean for Academic Programming, University of Michigan Law School.

1 A number of the papers presented at the colloquium were later published in the Summer/Autumn 2005 issue of Volume 68 of Law and Contemporary Problems. 
Dick served as my mentor. It would be difficult to overstate the formative impact of the opportunity to learn from him, and of my exposure to the ideas that were articulated, challenged, and further developed at that colloquium. Those experiences have shaped my career and scholarship, prompting me to apply for a job at the State Department Legal Adviser's Office after I graduated-and, while there, to take on a portfolio that included the United Nations Security Council targeted sanctions regimes. My scholarship since joining the faculty at the University of Michigan Law School has continued to wrestle with challenges of global governance that I first encountered as Dick's student and mentee. It is a great honor to contribute to this symposium celebrating Dick's fiftieth year of teaching.

In this Article, I address a topic that legal scholars tend to neglect: the funding of institutions that are engaged in regulation and governance. ${ }^{2}$ Both nationally and globally, decisions about funding are often less visible than decisions on substantive policies - though of course funding levels influence the extent to which those substantive policies will be implemented and their goals will be achieved. ${ }^{3}$

2 See Rachel E. Barkow, Insulating Agencies: Avoiding Capture Through Institutional Design, 89 TEX. L. REV. 15, 42 (2010) (describing funding as a "critical, though largely overlooked, key to [U.S. administrative agencies'] power"); HENRY G. SCHERMERS \& NiEls M. BlOKKER, InTERnATIONAL InSTITUTIONAL LAW 635 (6th rev. ed. 2018) (describing the financing of international organizations as a "somewhat neglected" topic in the literature on the law of international organizations); The Finances of Regional Organisations in the Global South: Follow THE MONEY (Ulf Engel \& Frank Mattheis eds., 2020) (observing that this neglect is especially severe with respect to regional organizations in the Global South and taking some steps to remedy it). This lack of attention to funding (or "resource mobilization," as insiders to organizations often refer to it) is an example of more general neglect of the internal policies and practices of international institutions. See Benedict Kingsbury, Operational Policies of International Institutions as Part of the Law-Making Process: The World Bank and Indigenous Peoples, in The REALITY OF INTERNATIONAL LAW: EsSAYS IN HONOUR OF IAN BROWNLIE (Guy S. Goodwin-Gill \& Stefan Talmon eds., 1999) (arguing that, although the internal policies and practices of international institutions are often neglected, they have "considerable significance for international law.").

3 See, e.g., Richard J. Lazarus, The Tragedy of Distrust in the Implementation of Federal Environmental Law, 54 LAW \& CONTEMP. PROBS. 311, 328-29 (1991) (describing how skeptics of U.S. environmental statutes were "reluctant to voice publicly their opposition to the passage of the statutes-because of the popular appeal of environmental protection - but they felt far more secure in undermining the statutory mandates in a less visible way through the appropriations process," and, as a result, "EPA has consistently received a level of funding far lower than 
While funding is a crucial factor for the entire range of institutions engaged in global governance, I focus here on formal international organizations, like the United Nations or the World Health Organization (WHO), and their growing reliance on voluntary contributions from member states. ${ }^{4}$ To date, such voluntary contributions have remained largely unregulated, at least by formal rules; I argue that formal regulations of such contributions are needed.

Typically, international organizations' member states pay "assessed contributions" - that is, membership dues that they set based on an agreed formula - to fund the organizations' regular budgets. ${ }^{5}$ Organizations' regular budgets have always been rather paltry, at least compared to their ambitious goals. In 1964, John Stoessinger observed that "the short history of international organizations has been marked by the tendency of states to invest only the most meager financial resources, and those grudgingly, in such institutions." 6 In the decades that followed, member states' willingness to fund international organizations' regular budgets continued to diminish. ${ }^{7}$ The economic havoc wrought by the COVID-19 pandemic will only accelerate this preexisting trend.

To supplement meager regular budgets, international organizations have turned to voluntary contributions from member states and non-state actors. ${ }^{8}$ While member states today still supply the vast majority of voluntary contributions, some private actors have made major contributions as well. In 1997, Ted Turner announced a \$1

the amount required to provide the agency with even a small chance of moderate success in implementing its statutory mandates.").

4 The Global Administrative Law literature identifies other types, which include transnational networks, hybrid intergovernmental-private arrangements, and private institutions with regulatory functions. See Benedict Kingsbury et al., The Emergence of Global Administrative Law, 68 LAW \& CONTEMP. ProBS. 15, 2023 (2005). Funding is a critical issue for these other types of governance arrangements as well. See, e.g., Sandra Moog et al., The Politics of Multi-Stakeholder Initiatives: The Crisis of the Forest Stewardship Council, 128 J. Bus. ETHICS 469, 478-81, 487 (2015).

5 See, e.g., U.N. Charter art. 17.

6 John G. Stoessinger, FinAnCing the United Nations System 3 (1964).

7 See SCHERMERs \& BlOKKER, supra note 2, at 688; Erin R. Graham, Money and Multilateralism: How Funding Rules Constitute IO Governance, 7 InT'L THEORY 162, 164 (2015); Kristina Daugirdas \& Gian Luca Burci, Financing the World Health Organization: What Lessons for Multilateralism?, 16 INT'L ORGS. L. REV. 299, 300 (2019).

8 Even the League of Nations turned to philanthropies to supplement its budget. See Susan Pedersen, The Guardians 7 (2015). 
billion gift to the United Nations; more recently, the Bill and Melinda Gates Foundation has become a top donor to WHO. ${ }^{9}$ Overall, the total value of voluntary contributions and their share of organizations' budgets are growing. ${ }^{10} \mathrm{WHO}$ and the International Organization for Migration (IOM) are on the far end of the spectrum: in recent years, voluntary contributions made up more than 80 percent of WHO's funding and more than 97 percent of IOM's funding. ${ }^{11}$ In addition, some programs and funds that are part of the United Nations, including the United Nations Environment Programme, rely entirely or almost entirely on voluntary contributions. ${ }^{12}$ Finally, some regional organizations depend heavily on contributions from sources other than member states. This situation is more common for organizations in the Global South, whose member states often face daunting economic challenges. ${ }^{13}$

At the same time that voluntary contributions are growing in size, they are changing along another dimension: voluntary contributions are increasingly earmarked for donors' preferred projects and come attached with various conditions. ${ }^{14}$ It is easy to see why

9 Christopher G. Bradley, Partner Capture in Public International Organizations, 44 AKron L. REV. 261, 263 (2011); Daugirdas \& Burci, supra note 7, at 301.

10 See SCHERMERS \& BlOKKER, supra note 2, at 688 (noting the overall trend and citing Interpol as an example); Graham, supra note 7, at 183-87 (describing growth of voluntary contributions in the U.N. system).

11 See Daugirdas \& Burci, supra note 7, at 299; François Crépeau (Special Rapporteur on the Human Rights of Migrants), Report of the Special Rapporteur on the Human Rights of Migrants, para. 114, U.N. Doc. A/68/283 (Aug. 7, 2013).

12 See Daugirdas \& Burci, supra note 7, at 301 n. 10 (describing the extent of reliance on voluntary contributions by the U.N. Development Program ("entirely"), the U.N. Environment Program (95\%), UNICEF ("exclusively"), the World Food Program ("entirely"), and the U.N. Office of the High Commissioner for Refugees ("almost entirely")). See also Eric Rosand \& Alistair Millar, The Odd Couple at the Center of the U.N. 's Counterterrorism Growth, JUST SECURITY (July 8, 2020), https://www.justsecurity.org/71273/the-odd-couple-at-the-center-ofthe-u-n-s-counterterrorism-growth/ (noting that since its establishment in 2017, the U.N. Office of Counter-Terrorism has expanded rapidly to more than 150 staff in New York, with additional personnel in six field offices around the globe. "Yet, only eight of these positions are funded out of the regular U.N. budget, which accounts for less than 5 percent of UNOCT's resources.").

13 See Ulf Engel \& Frank Mattheis, The Finances of Regional Organisations in the South: Challenges of Studying a Neglected Facet of Regionalism, in THE FinANCES of Regional ORganisations in the Global SoUth: Follow the MONEY, supra note 2, at 1 .

14 See Daugirdas \& Burci, supra note 7; Graham, supra note 7, at 183-85. 
donors prefer to give earmarked contributions: donors can direct funds to the projects they find most appealing, perhaps because they judge certain projects more likely to be effective or because, in the case of member-state donations, they find certain projects easier to justify to the national legislatures that hold the purse strings. ${ }^{15}$ But voluntary contributions have some downsides, especially if they make up a large fraction of an organization's budget. Heavy reliance on voluntary contributions can erode multilateral governance of international organizations and can compromise their work.

Among the three main components of international organizations' incomes - assessed contributions, voluntary contributions from member states, and voluntary contributions from non-state actors - international lawyers have devoted the most attention to the first category. They have scrutinized questions about whether and when member states might have a legal right to withhold contributions and the consequences of nonpayment that lacks legal justification. ${ }^{16}$ By contrast, because states are not obliged to supply voluntary contributions, such contributions generate fewer legal questions. ${ }^{17}$ As for the third category, legal scholars have begun to pay attention to financial contributions from private actors on account of the distinct risks associated with such contributions. ${ }^{18}$

15 See, e.g., Andrew Siddons, McConnell Gets Personal Discussing Polio, Roll CALL (July 10, 2018), https://www.rollcall.com/2018/07/10/mcconnellgets-personal-discussing-polio/ (tracing Senator Mitch McConnell's support for the WHO's polio-eradication programs to McConnell's childhood experience with polio); Vera Z. Eichenauer \& Bernhard Reinsberg, What Determines Earmarked Funding to International Development Organizations? Evidence from the New Multi-Bi Aid Data, 12 REV. INT'L ORGS. 171, 171, 186-88 (2017) (systematically reviewing motives for why donor countries give earmarked aid and presenting empirical evidence that "earmarked aid serves many purposes"). For a discussion of the types of projects that regularly fail to attract voluntary contributions, see Daugirdas \& Burci, supra note 7, at 317-20.

16 See, e.g., José E. Alvarez, Legal Remedies and the United Nations' a la Carte Problem, 12 Mich. J. INT'L L. 229 (1991); Elizabeth Zoller, The Corporate Will of the United Nations and the Rights of the Minority, 81 AM. J. INT'L L. 610 (1987); Francesco Francioni, Multilateralism à la Carte: The Limits to Unilateral Withholdings of Assessed Contributions to the UN Budget, 11 EUR. J. INT'L L. 43 (2000).

17 See James E. Archibald, Pledges of Voluntary Contributions to the United Nations by Member States: Establishing and Enforcing Legal Obligations, 36 GEO. WASH. INT'L L. REV. 317, 317-18 (2004).

18 See Bradley, supra note 9, at 261-63; LilianA B. Andonova, Governance Entrepreneurs 76-88 (2017); Ayelet Berman, Between Participation and Capture in International Rule-Making: The WHO Framework of 
Member states, too, have taken action to address such contributions. In 2016, the World Health Assembly adopted a Framework for Engagement with Non-State Actors (FENSA), which was the first effort in the U.N. system to comprehensively regulate WHO's interactions - including fundraising - with the private sector, philanthropic foundations, non-governmental organizations, and academic institutions. ${ }^{19}$

To the extent that scholars and practitioners have focused on voluntary contributions from member states, the main solutions they have advanced are increasing assessed contributions and reducing the level and extent of earmarks on voluntary contributions. ${ }^{20}$ Such efforts are worthwhile, but they have yielded only modest results, as earmarked contributions have continued to grow. The pressures on governments to earmark their contributions to international organizations are unlikely to relent. Indeed, the trend towards earmarked giving extends to other areas of philanthropic giving and is not limited to contributions to international organizations. ${ }^{21}$

Engagement with Non-State Actors, 32 EuR. J. INT'L L. 227 (2021). See also Margaret H. Lemos \& Guy-Uriel Charles, Patriotic Philanthropy: Financing the State with Gifts to Government, 106 CALIF. L. REV. 1129 (2018) (addressing such gifts at the national and local level).

19 See WHO, World Health Assembly Res. 69.10, Framework of Engagement with Non-State Actors, WHO Doc. A69/VR/8 (May 28, 2016) [hereinafter FENSA].

20 The most sophisticated and extensive effort on this front is the development of the Voluntary Indicative Scale of Contributions at the U.N. Environment Programme (UNEP), which sought to broaden the donor base to UNEP and increase the levels of unearmarked voluntary contributions to UNEP's Environment Fund. These efforts were successful in the initial phases of their implementation, but less so in recent years. See U.N. Economic and Social Council [ECOSOC], Independent Team of Advisers, A New Funding Architecture of the UN Development System for the 2030 Agenda: Options and Challenges, Annex IV (Mar. 29, 2016), https:/www.un.org/ecosoc/sites/www.un.org.ecosoc/files/files/en/qcpr/ecosocdialogue-funding-of-unds.pdf; Executive Director of U.N. Environment Programme, Voluntary Indicative Scale of Contributions, I 13, U.N. Doc. UNEP/EA.4/INF/11 (Feb. 13, 2019).

21 See, e.g., Joye Mercer, Strings Attached, Chron. Higher Ed. (Mar. 10, 1995 ) (noting that "[o]n more and more campuses, donations for unrestricted purposes are barely holding steady, while restricted giving - money for specific goals and programs - has been climbing fast'); Strobe Talbott \& Kimberly Churches, Safeguarding Charity Independence, CHRON. PhILANThropy (Feb. 2, 2016) (describing a "surge" in "project-based - that is, restricted-funding" to charitable organizations as "more and more donors are concentrating on projects that are in line with their own civic, cultural, intellectual, and humanitarian interests."). 
This Article advances a different solution: regulating voluntary contributions from member states. Part I elaborates on the risks associated with such contributions. Part II describes the mix of formal and informal policies and practices that currently regulate such contributions and argues that these policies are insufficient. Part III outlines several possibilities for developing more comprehensive, formal regulation of voluntary contributions.

\section{WHY WORRY?}

When earmarked voluntary contributions make up a significant fraction of an organization's budget, the governance bodies formally tasked with determining the organization's budget may lose control over the organization's priorities and activities. ${ }^{22}$ In the extreme case, individual donors would choose which activities to fund. The organization's activities would not be the result of a coherent strategy or plan, nor would they be determined through a transparent and deliberative process. Instead, the organization's activities would reflect the aggregate of individual donors' decisions. Moreover, long-term planning would be challenging, if not impossible, due to the unpredictability of voluntary contributions. ${ }^{23}$ The result has been characterized as "Trojan multilateralism"- a veneer that masks the dominance of individual donors' goals and interests within multilateral organizations. ${ }^{24}$ These concerns about hollowing out governance mechanisms may be especially acute when donors are private entities or non-member states who have no formal role in governing the organization. ${ }^{25}$

Moreover, member states may use their voluntary contributions to advance their own national agendas and thereby undermine the international character of international organizations. For example, sometimes donor states seek to preclude WHO from using voluntary

22 See Graham, supra note 7, at 185-90.

23 See Archibald, supra note 17, at 317.

24 See Devi Sridhar \& Ngaire Woods, Trojan Multilateralism: Global Cooperation in Health, 4 GLOB. POL'y 325 (2013); Jacob Katz Cogan, Financing and Budgets, in THE OXFORD HANDBOOK OF INTERNATIONAL ORGANIZATIONS 903, 918-19 (Jacob Katz Cogan et al. eds., 2016).

25 See, e.g., Nickson Bondo Museka, The Finances of the International Conference of the Great Lakes Region (ICGLR), in THE FINANCES OF REGIONAL ORGANiSATIONS IN THE GLOBAL SOUTH: Follow THE MONEY, supra note 2, at 76 (observing that the priorities of ICGLR's external funders differ from those of member states). 
contributions to assist states on which the donor state has imposed unilateral sanctions. ${ }^{26}$ Sometimes donor states condition voluntary contributions on WHO's hiring of the donor state's nationals to implement the funded project. $^{27}$

International organizations' reliance on voluntary contributions is particularly troubling for certain kinds of work. One category is normative work, such as setting standards and identifying best practices. The risk here is that instead of reflecting the organization's best expert judgment and an international perspective, the normative work will reflect, for example, the donors' desire to protect or enhance powerful domestic industries. Even in the absence of actual influence, the perception that the integrity of an international organization's normative work has been compromised may make the organization's normative work less trusted and less effective.

Similarly vulnerable is work that involves evaluating the conduct of member states and holding those states accountable, including through public criticism, when they fall short. The concern here is that, in response to subtle or overt pressure, secretariat staff will selectively refrain from such criticism to avoid losing voluntary contributions. Strikingly, numerous offices and programs whose work actually or potentially involves such evaluation and criticism rely quite heavily on voluntary contributions. For example, the Office of the U.N. High Commissioner for Human Rights (OHCHR) had a $\$ 179$ million budget in 2019 , with voluntary contributions furnishing 63 percent of this total. ${ }^{28}$

The fewer the donors, the greater the unease about voluntary contributions funding such work. For example, voluntary contributions from Qatar and Saudi Arabia supply more than 80 percent of the budget of the U.N. Office of Counter-Terrorism; commentators have suggested that reliance on these funds explains the office's scant "appetite for properly addressing human rights violations that arise from a member state's counterterrorism laws and

26 See Daugirdas \& Burci, supra note 7, at 327 (describing the role of the WHO's legal office in screening funding agreements for such provisions).

27 See id.

28 See OHCHR's Funding and Budget, U.N. OFF. OF THE HigH COMM'R FOR HuM. RTS., https://www.ohchr.org/EN/AboutUs/Pages/FundingBudget.aspx (last visited Mar. 25, 2021). The Inter-American Commission on Human Rights relied on voluntary contributions to overcome a severe financial crisis in 2016. See Karima Bennoune, In Defense of Human Rights, 52 VAND. J. TRANSNAT'L L. 1209, 1210 n.3 (2019). 
operations. ${ }^{29}$ In 2016, Saudi Arabia threatened U.N. SecretaryGeneral Ban Ki-moon with cutting funding to counterterrorism and humanitarian relief programs unless Ban removed the "Saudi Arabia-led coalition" in Yemen from its published list of parties to armed conflict that commit grave violations against children. ${ }^{30}$ Ban succumbed to that pressure. Unusually, he acknowledged doing so in a press conference shortly thereafter:

I . . had to consider the very real prospect that millions of other children would suffer grievously if, as was suggested to me, countries would defund many UN programmes. Children already at risk in Palestine, South Sudan, Syria, Yemen, and so many other places would fall further into despair.... I'm Chief Administrative Officer of this Organization. ... I had to make a decision to keep all United Nations operations, particularly humanitarian operations, continuing. ${ }^{31}$

Ban may have been more willing to speak out in this instance because he was nearing the end of his tenure as Secretary-General: he would not need to beseech Saudi Arabia for cooperation and financial assistance much longer. ${ }^{32}$ Perhaps Ban judged that, at that moment, he personally could draw the fire with less risk to the United Nations as a whole.

\section{REgUlation OF VOLUNTARY CONTRIBUTIONS FROM MEMBER STATES}

Overall, very few formal policies govern voluntary contributions from member states. WHO is an illuminating case study because it is at the extreme end of international organizations in the degree to which it relies on voluntary contributions. This Part first

29 Rosand \& Millar, supra note 12.

30 See U.N. Secretary-General, Children and Armed Conflict, ๆๆ 164-175, U.N. Doc. A/70/836-S/2016/360 (Apr. 20, 2016). Accord Colum Lynch, Saudi Arabia Threatened to Break Relations with U.N. Over Human Rights Criticism in Yemen, FoREIGN POL'y (June 7, 2016), https://foreignpolicy.com/2016/06/07/saudi-arabia-threatened-to-break-relations-with-un-over-human-rights-criticismin-yemen/.

31 U.N. Secretary-General, Full Transcript of Secretary-General's Press Encounter (June 9, 2016), https:/www.un.org/sg/en/content/sg/press-encounter/2016-06-09/full-transcript-secretary-generals-press-encounter.

32 Ban's term ended December 31, 2016, only seven months after the press conference. See Former Secretary-General Ban Ki-Moon, UnITED NATIONS, https://www.un.org/sg/en/formersg/ban.shtml (last visited Apr. 17, 2021). 
details the formal policies that exist at WHO for mitigating the risks described above and some of the informal practices that supplement them. This Part then explains why such informal strategies are not up to the task.

\section{A. Formal and Informal Policies and Practices at WHO}

From quite early in its history, WHO has explored creative ways to identify and tap sources of income beyond its assessed contributions from governments. ${ }^{33}$ The WHO Constitution supplies a clear legal basis for doing so. Article 57 provides:

The Health Assembly or the [Executive] Board acting on behalf of the Health Assembly may accept and administer gifts and bequests made to the Organization provided that the conditions attached to such gifts or bequests are acceptable to the Health Assembly or the Board and are consistent with the objective and policies of the Organization. ${ }^{34}$

In turn, the Health Assembly delegated to the Director-General the authority to accept such gifts and bequests, "provided that he or she has determined that such contributions can be used by the Organization, and that any conditions which may be attached to them are consistent with the objective and policies of the Organization." 35

Member states and the WHO secretariat have both taken steps to address the first set of concerns described in the previous Part: that reliance on voluntary contributions will hollow out the organization's formal governance bodies and impede coherent decisionmaking across the range of WHO's activities and planning over time. As former WHO Director-General Margaret Chan put it:

We can take some pride in the fact that voluntary contributions have increased steadily and substantially. In a sense, this expresses confidence that support for the work of WHO is a good investment.

33 See STOESSINGER, supra note 6, at 220-26 (detailing WHO's early efforts to sell stamps and seals to the public, to secure loans from the World Bank, and to establish various special funds for collecting contributions from governments as well as from foundations, industries, labor organizations, and individuals).

34 WHO Const. art. 57.

35 WhO, Financial Regulations and Financial Rules of the World Health Organization, Regulation 8.1 (2014). 
But it shapes the agenda beyond the control of Member States, lets resources drive priorities, and greatly diminishes MemberState oversight of resources and expenditures. ${ }^{36}$

Chan proposed that the Health Assembly start approving the entire WHO budget, not just the portion financed by assessed contributions. She explained: "Doing so would be a major departure from past practices and would return the responsibility for oversight to Member States." ${ }^{37}$ In 2013, the World Health Assembly adopted Chan's proposal and inaugurated new budget practices. ${ }^{38}$ To better align voluntary contributions with the approved budget, the Health Assembly's budget resolutions began imposing budget ceilings on voluntary contributions, capping the total amount that the organization could collect both overall and in each of the six categories of its work. ${ }^{39}$ The budget resolutions also granted the WHO DirectorGeneral greater flexibility to direct assessed contributions to programs that struggled to attract voluntary contributions. ${ }^{40}$

Separately, the WHO secretariat sought to persuade member states to eliminate, or at least to "lighten" restrictions and conditions on their voluntary contributions. ${ }^{41}$ Around 2004, WHO established a specified category of "core voluntary contributions" that could be used at the Director-General's discretion to close budgetary gaps and support programs that failed to attract much voluntary funding. ${ }^{42}$ This category has not proved particularly appealing to member states; during the 2016-17 biennium, only 4 percent of all voluntary contributions were "core" contributions. ${ }^{43}$ More recently, recognizing the reticence among many donors to provide wholly unrestricted funds, the secretariat has shifted to a strategy of working with donors to "reshape" their voluntary contributions so that

36 WHO, Director-General Addresses Reforms in WHO Financing, (Dec. 6, 2012), https:/www.who.int/director-general/speeches/detail/director-general-addresses-reforms-in-who-financing.

37 Id.

38 See Daugirdas \& Burci, supra note 7, at 313-15.

39 See id. at 315.

40 See id.

41 Id. at 327. For a broader discussion of "earmarking intensity," see Eichenauer \& Reinsberg, supra note 15, at 174.

42 See Daugirdas \& Burci, supra note 7, at 324-25.

43 World Health Organization, WHO REsults RePort: PROGRAMME BudGET 2016-2017, at https:/www.who.int/about/finances-accountability/budget-portal/rr_2016-17.pdf. 
earmarks are less restrictive with respect to geography, subject matter, or both. ${ }^{44}$

With respect to the second risk described above - that member states will impose conditions on voluntary funds that are inconsistent with WHO's international character-WHO does not have any formally promulgated policies that enumerate the kinds of conditions that might not be "consistent with the objectives and policy of the Organization." ${ }^{45}$ Instead, it falls to the WHO legal office to screen voluntary contributions to eliminate such conditions or requirements. $^{46}$

When it comes to protecting its normative, standard-setting work from actual or perceived influence by funders, the World Health Assembly has adopted a formal policy regarding funding from non-state actors. Among other things, FENSA prohibits WHO from accepting financial or in-kind contributions from private-sector entities for its normative work. ${ }^{47}$ But there is no parallel policy regulating voluntary contributions from member states. Instead, WHO officials take steps to mitigate the risks associated with such contributions on a "case-by-case" basis. ${ }^{48}$ The officials that run individual offices make a point of trying to avoid relying on single donors to fund their normative projects. ${ }^{49}$

As for work that involves publicly criticizing member states where they fall short, the WHO secretariat largely avoids it. WHO's heavy reliance on voluntary contributions may help to explain this nonconfrontational approach. During the SARS outbreak in 2003, then-Director General Gro Harlem Brundtland criticized China for its lack of transparency, saying:

It would have been better if the Chinese government had been more open in the early stages, from November to March. ... We were asking questions, wanting to send in experts to help identify the source. It took too long before they felt the need to be helped. Next time something strange and new comes ... let us in as soon as possible. ${ }^{50}$

44 Daugirdas \& Burci, supra note 7, at 327-28.

45 See WHO Const. art. 57; id. at Regulation 8.1.

46 See Daugirdas \& Burci, supra note 7, at 327.

47 See FENSA, supra note 19, at 25.

48 See Daugirdas \& Burci, supra note 7, at 327.

49 See id.

50 Thomas Abraham, Twenty-First Century Plague 101 (2007). 
All things considered, Brundtland's reproach was fairly mild; nevertheless, her comments garnered significant attention because they reflected a significant break from WHO's standard modus operandi of quiet, behind-the-scenes diplomacy. ${ }^{51}$ Spurred to action by the SARS outbreak, the World Health Assembly revised the International Health Regulations governing disease outbreaks in $2005 .^{52}$ These revisions provided an opening for the WHO Director-General to make public criticism of member states a standard practice: the revised Regulations require the Director-General to report to the Health Assembly on the implementation of the new Regulations. ${ }^{53}$ States' lackluster implementation has provided plenty of fodder for such criticism. ${ }^{54}$ Yet year after year, Directors-General have refrained from "naming and shaming" noncomplying states. The secretariat's reports present data on compliance in a "consolidated, deidentified format." ${ }^{55}$ The secretariat's analysis of specific instances of alleged violations is posted on a website that is not available to the public. ${ }^{56}$

One final WHO practice with respect to voluntary contributions that is worth mentioning concerns transparency and reporting. Each year, WHO releases information about the voluntary contributions it receives from member states and from other sources. ${ }^{57}$ These annual reports identify donors and the size of their contributions. Importantly, however, while these reports identify earmarked voluntary contributions as a category, they do not specify the nature of

51 Like Ban Ki-moon in the example described above, Brundtland made these comments in the final months of her term as Director-General. See Gavin Yamey, Head of WHO to Stand Down, 325 BRIT. MED. J. 457, 457 (2002) (noting that Brundtland's term of office ended in July 2003).

52 See WHO, InTERnational HeAlth Regulations (3d ed. 2005).

53 See id. art. 54(1).

54 See Adam Kamradt-Scott, The International Health Regulations (2005): Strengthening Their Effective Implementation and Utilisation, 16 INT'L ORGS. L. REV. 242, 251-52 (2019) (describing states' noncompliance with the International Health Regulations in connection with the 2009 H1N1 influenza pandemic and the 2014-2016 West African Ebola outbreak).

55 Id. at 251-52, 255.

56 Gian Luca Burci, The Outbreak of COVID-19 Coronavirus: are the International Health Regulations fit for purpose? EJIL:Talk! (Feb. 27, 2020), https://www.ejiltalk.org/the-outbreak-of-covid-19-coronavirus-are-the-international-health-regulations-fit-for-purpose/.

57 See, e.g., WHO, Voluntary Contributions by Fund and by Contributor, 2019, U.N. Doc. A73/INF./3 (June 29, 2020). 
the earmarks. ${ }^{58}$ Nor are other conditions or requirements associated with the contribution reported. ${ }^{59}$ The absence of this information makes it impossible to determine, for example, the extent to which secretariat staff succeeded in finding multiple donors to support its normative work.

\section{B. Problems with Reliance on Informal Practices}

There are a number of reasons to doubt the adequacy of informal policies and practices as a bulwark against the risks associated with voluntary contributions from member states. Informal policies are, by definition, not transparent to those outside an international organization. Outsiders will struggle to discern and evaluate the content of those policies and their underlying rationales. Just as importantly, the policies and practices of individual offices may not be entirely transparent within an organization. Absent formal written policies, there is no guarantee that all of the various offices within an international organization are consistently applying the same policies and following the same practices to mitigate the risks associated with voluntary contributions from member states. The development and implementation of such policies and practices depends on the priorities, effectiveness, and commitment of the individuals involved.

Consider again the U.N. Office of the High Commissioner for Human Rights (OHCHR); as noted above, more than 60 percent of its budget currently comes from voluntary contributions. ${ }^{60}$ Unlike the WHO Director-General, the High Commissioner for Human Rights criticizes U.N. member states rather frequently. ${ }^{61}$ Indeed, the willingness to do so is an essential component of the High Commissioner's job. When former High Commissioner Zeid Ra'ad Zeid AlHussein announced that he would not seek a second term in 2017, he expressed his fear that the need to secure the votes for a second

58 See, e.g., id.

59 See, e.g., id.

60 See OHCHR's Funding and Budget, supra note 28.

61 See, e.g., Jennifer Hansler, Haley Hits UN Human Rights Office Over Condemnation of US Immigration Policy, CNN (June 5, 2018), https://www.cnn.com/2018/06/05/politics/un-human-rights-southern-border-families/index.html; Kristina Daugirdas, Reputation as a Disciplinarian of International Organizations, 113 AM. J. INT'L L. 221, 247-48, 258-60 (2019) (describing the High Commissioner's willingness to publicly criticize France when other U.N. officials pointedly declined to do so). 
term might cause him to hold back from making such criticisms of member states or their allies: seeking a second term "in the current geopolitical context might involve bending a knee in supplication; muting a statement of advocacy; lessening the independence and integrity of my voice." 62 This point would seem to generalize to other "asks" that the High Commissioner might make of member states, including for voluntary contributions.

It is not clear what steps OHCHR takes to protect against the risk that funding decisions might influence - or might appear to influence-its work. OHCHR's website notes that the majority of the voluntary contributions it received were earmarked, and that in 2019 approximately 60 percent of voluntary contributions "[were] used to support work in the field," while the remainder was "distributed between other areas of the Office's work." ${ }^{63}$ Like WHO, OHCHR publishes on its website and in annual reports information about the identities of its donors and the amounts that they gave. ${ }^{64}$ The annual reports identify categories of earmarked contributions, but they do not reveal any details about the earmarks or other conditions that individual donors imposed on their contributions. ${ }^{65} \mathrm{OHCHR}$ 's policies and practices governing its acceptance of voluntary contributions remain informal or at least not publicly available.

Even when rules within bureaucracies are formalized, there is a risk of what Michael Barnett and Martha Finnemore labeled a "normalization of deviance." 66 One feature of bright-line rules is that, in some subset of cases, applying those rules will lead to outcomes that disserve the goals that motivated the development of the rule in the first place. In such cases, bureaucracies may have some capacity to carve out targeted exceptions. The risk, Barnett and

62 Somini Sengupta \& Nick Cumming-Bruce, Zeid Ra'ad al-Hussein, Top Human Rights Official, Won't Seek a Second Term, N.Y. TimeS (Dec. 20, 2017), https://www.nytimes.com/2017/12/20/world/un-human-rights-al-hussein.html.

63 OHCHR's Funding and Budget, supra note 28.

64 See, e.g., United NATions Human Rights: OfFice of the High COMMISSIONER, VOLUNTARY CONTRIBUTIONS TO OHCHR IN 2020 (2020), https://www.ohchr.org/Documents/AboutUs/FundingBudget/VoluntaryContributions2020.pdf.

65 See, e.g., United Nations Human Rights: Office of the High Commissioner, United Nations Human Rights Report 2019, at 84-109 (2020), https://www2.ohchr.org/english/OHCHRreport2019/.

66 Michael N. Barnett \& Martha Finnemore, The Politics, Power, and Pathologies of International Organizations, 53 INT'L ORG. 699, 721-22 (1999). 
Finnemore explain, is that over time, the exception will swallow the rule: "what at time $\mathrm{t}_{l}$ might be weighed seriously and debated as a potentially unacceptable risk ... comes to be treated as normal at time $t_{n} .{ }^{, 67}$ When policies and practices are informal, such normalization of deviance is even more likely.

Indeed, as applied to policing voluntary contributions from member states, the pressure to create exceptions seems especially high. By challenging conditions attached to voluntary contributions or refusing such contributions altogether, officials may provoke the ire of member states. International civil servants have powerful incentives to maintain positive relationships with member states. ${ }^{68}$ Moreover, international organizations compete for funding with other possible recipients. By challenging conditions attached to a voluntary contribution, the organization risks losing the contribution and thereby the capacity to undertake the work that the contributions would fund. In soliciting voluntary contributions, international organizations are negotiating from a position of weakness. Under such circumstances, international organizations face big incentives to find a way to accommodate donor states' demands.

The development and implementation of informal policies to protect international organizations from the risks associated with voluntary contributions is vulnerable to another trend that is affecting many international organizations: their growing reliance on short-term contracts instead of regular staff posts. ${ }^{69}$ A 2012 Joint Inspection Unit (JIU) report indicated that around 45 percent of the total personnel of the organizations that make up the U.N. system were working under non-staff contracts. ${ }^{70}$ Non-staff personnel frequently outnumber staff at international organizations that rely

67 Id. at 722.

68 See Daugirdas, supra note 61, at 228, 247-48 (2019) (observing that the apparent organizational imperative to maintain a reputation for cooperativeness with member states aligns with the micro-level incentives that individual IO employees face not to pick fights with member states).

69 See generally Andrés Muñoz Mosquera, On the Notion of Precarious Employment in International Organizations, 11 INT'L ORGS. L. REV. 294 (2014).

70 See Cihan Terzi \& Papa Louis Fall, U.N. Joint Inspection Unit, Use of NonStaff Personnel and Related Contractual Modalities in the United Nations System Organizations, U.N. Doc. JIU/Rep/2014/18, at 3 (2014) [hereinafter JIU Report]. 
heavily on voluntary contributions. ${ }^{71}$ This recent growth in precarious employment at international organizations mirrors trends in the national economies of member states. ${ }^{72}$

In describing the consequences for international organizations, Andrés Muñoz Mosquera, a NATO legal adviser, distinguished between two types of staff allegiances: allegiance to the goals or purposes of an international organization and allegiance to the organization itself. $^{73}$ The insecurity associated with temporary employment may not disturb the former but, Mosquera argued, is quite likely to erode the latter. ${ }^{74}$ This argument makes intuitive sense: individuals who do not feel protected by an organization may well feel little reciprocal obligation to protect the organization, especially if the risks to the organization from accepting a particular voluntary contribution seem theoretical or will manifest only in the long-term. Temporary employees may be less like to identify such risks, to be troubled by those risks, and to go out of their way to mitigate or avoid such risks in order to protect the organization.

Precarious employment may undermine the development and implementation of informal policies regarding voluntary contributions in another way as well. Non-staff employment is often, but not always, short-term. ${ }^{75}$ A JIU survey of non-staff personnel revealed that roughly half had stayed with the same organization for fewer than five years while half had stayed for more than five years. ${ }^{76}$ Personnel who stay with an organization for a shorter time have less opportunity to acquire experience and expertise; they also have less opportunity to pass on their experience to their colleagues. ${ }^{77}$ Moreover, with constant churn among staff, it is less likely that informal rules and their underlying rationales will be clearly and comprehensively communicated to all staff who ought to be implementing

71 See id. at 75 (indicating that non-staff make up more than 50 percent of the total workforce at UNDP, FAO, and WHO, among other organizations and programs).

72 See Mosquera, supra note 69, at 313-14, 316. See also JIU Report, supra note 70 , at 18 (noting that, inter alia, budgetary restrictions, lack of resources, and unpredictable funding are among the reasons for hiring non-staff personnel).

73 See Mosquera, supra note 69, at 301.

74 See id.

75 See JIU Report, supra note 70 at 48, 73.

76 See id. at 73.

77 Kirti Datla \& Richard L. Revesz, Deconstructing Independent Agencies (and Executive Agencies), 98 CORNELl L. REV. 769, 792 (2013). 
them. The ever-present risk that exceptions will swallow rules only grows in this context. ${ }^{78}$ For all these reasons, continuity and consistency in implementing informal policies is likely to be particularly difficult to maintain in the current environment.

\section{NEXT STEPS}

In light of the deficiencies of relying on informal policies and practices to mitigate the risks associated with voluntary contributions from states, it is worth considering what more formal regulations might look like. ${ }^{79}$ A big obstacle to offering up a set of substantive rules is a lack of information about current informal practices, including how much they vary within and across organizations, how those variations are justified, and how insiders - much less outsiders - evaluate the adequacy of those practices. This lack of information means that, for example, proposing specific amendments to organizations' financial rules and regulations is premature at this point. Instead, the crucial first step is more disclosure and discussion of existing policies and practices, especially the informal ones.

Even under these circumstances, it is possible to outline some options and considerations that ought to guide the development of formal regulations. To start, such regulations might focus on substance or procedure. Substantive regulations might enumerate the kinds of conditions on voluntary contributions that are prohibited. In addition, they might address how the earmarks for voluntary contributions must relate to various decisions that are made by the secretariats or by member states, such as annual or biannual budgets or multi-year strategic plans. Substantive regulations might also set a minimum number of donors for a given project or set a ceiling on the share of funds for a project that can be provided by a single donor.

Another question for substantive regulations is whether they ought to be hortatory or mandatory. Such substantive regulations might come in the form of recommendations or best practices, or

78 See supra notes 66-67 and accompanying text (describing Barnett and Finnemore's discussion of the "normalization of deviance").

79 By way of comparison, consider the factors that make governments' acceptance of gifts from private philanthropists more and less problematic. See Lemos \& Charles, supra note 18, at 1133-35 (2018). 
they might be firmer requirements backed up by penalties - such as disciplinary proceedings - for noncompliance. The World Bank's process for initiating loans, for example, is regulated by a mix of aspirational targets and mandatory requirements. To assure compliance with the mandatory requirements, the Bank has established both internal mechanisms - like random audits and post-project review - and an independent external mechanism that allows individuals who have been harmed by noncompliance with the Bank's mandatory requirements to bring complaints. ${ }^{80}$

Separately, procedural regulations might serve as an alternative or as a supplement to such substantive regulations. Process regulations might specify who within the organization's secretariat must approve individual contributions before they are accepted or who must approve deviations from best practices or other requirements. Process regulations might also require disclosures regarding the nature of earmarks, conditions, or the number of funders for individual projects. Such disclosures might be made to member states, to the public, or to both. Disclosure to member states alone, however, would probably fail to provoke much-needed deliberation and action. $^{81}$

For both substantive and procedural regulations, there is an additional question of how and by whom the implementation of these regulations will be policed. In any organization - and for any policy - there may be gaps between what the formal policy prescribes and what happens on the ground. In some cases, the failure to follow through and ensure implementation can reflect a deliberate effort to insulate on-the-ground operations from the formal policy. ${ }^{82} \mathrm{~A}$ related concern is the possibility that donors' demands in connection with voluntary contributions will be increasingly communicated informally rather than being documented in formal funding arrangements; such "gentlemen's agreements" regarding various aspects of

80 See Laurence Boisson de Chazournes, Policy Guidance and Compliance: The World Bank Operational Standards in COMMITMENT \& COMPLIANCE 291-92 (Dinah Shelton ed., 2003).

81 See Burci, supra note 56.

82 See John W. Meyer \& Brian Rowan, Institutionalized Organizations: Formal Structure as Myth and Ceremony, 83 AM. J. Socio. 340, 355-56 (1977) (identifying the phenomenon of decoupling - the adoption of formal structures that are needed to legitimate organizations while insulating on-the-ground operations from those formal structures); CATHERINE WEAVER, HYPOCRISY TRAP 28 (2008) (extending and applying this analysis to international organizations). 
governance and operation of international organizations are not uncommon. ${ }^{83}$

A final consideration is how formal regulation of voluntary contributions would affect dynamics among international organizations, especially because international organizations compete with one another for voluntary contributions. Those dynamics might be positive. The process of developing such regulations could contribute to useful learning and dissemination of best practices among international organizations. ${ }^{84}$ Moreover, the competition among organizations could yield a race to the top, as organizations seek to bolster the legitimacy - and therefore enhance the efficacy - of their normative outputs. But that competition could also provoke a race to the bottom, as organizations seek to attract more funding by putting up fewer obstacles to donors' ability to get their way.

\section{CONCLUSION}

Although this Article has focused on the risks associated with earmarked voluntary contributions from member states, it is important to avoid an unduly negative view of this source of funding for international organizations. Voluntary contributions have some advantages, including that they can be mobilized quickly in crisis situations, and they can make international organizations less vulnerable to the problems caused by withholding assessed contributions. ${ }^{85}$ All sources of funding for international organizations have both benefits and risks. The key is to acknowledge those risks and take steps to mitigate them.

83 See Jacob Katz Cogan, Representation and Power in International Organization: The Operational Constitution and Its Critics, 103 AM. J. INT'L L. 209, 234 (2009) (describing links between U. S. funding for the U.N. Development Program and the nationality of the UNDP administrator).

$84 C f$. Laurence Boisson de Chazournes, Partnerships, Emulation, and Coordination: Toward the Emergence of a Droit Commun in the Field of Development Finance, in 3 WORLD BANK LEGAL REV. 173, 174 (Hassane Cissé et al. eds., 2011) (describing the diffusion of policies, rules, and procedures regarding development finance among multilateral development banks).

85 See Daugirdas \& Burci, supra note 7, at 332-36. 